\title{
A REVIEW OF SECURITY INTEGRATION TECHNIQUE IN AGILE SOFTWARE DEVELOPMENT
}

\author{
Raja Khaim ${ }^{1}$, Saba Naz ${ }^{* 1}$, Fakhar Abbas $^{2}$,Naila Iqbal ${ }^{3}$, Memoona Hamayun ${ }^{5}$ \\ ${ }^{1,2,3,4}$ University Institute of Information Technology, PMAS University,
}

Rawalpindi Pakistan

\begin{abstract}
Agile software development has gained a lot of popularity in the software industry due to its iterative and incremental approach as well as user involvement. Agile has also been criticized due to lack of its ability to deliver secure software. In this paper, extensive literature has been performed, in order to highlight the existing security issues in agile software development. Majority of challenges reported in literature, occurred due to lack of involvement of security expert. Improving security of a software system without damaging the real essence of Agile can achieved with the continuous involvement of security engineer throughout development lifecycle with its defined role and responsibilities.
\end{abstract}

\section{KEYWORDS}

Agile development, Agile Security Development

\section{INTRODUCTION}

Agile practices have a significant impact in developing software in recent few years [1]. A fair amount of affirmative response has been noted from organizations [2] that use agile practices. These practices are quite popular for producing evolving software's [3]. Agile practices are related to improved product quality, customer satisfaction, and developer productivity than traditional waterfall practices [4]. Over the period of time one of significant concern is software security. Up to certain level security is successfully integrated in traditional development by developers [5], but there is some serious criticism of agile development methodology to produce less secure software's [6], [7].

Acceptance of changing requirements, favoring regular deliveries, and exclusion of security engineering activities make secure software development challenging using agile methodology [8].This leads agile practices reiteration in respect of making secure software, which negatively affects project timeline, considerable increase in costs, and decreased customer belief and satisfaction, which in the end diminishes the notion of these practices as agile [9]. These 
characteristics serve as the foundation of serious criticism on agile methods to produce unsecure software's.

In this study the analysis of related work is mostly revealed about the issues of integration of security in agile. This paper presents the systematic review of techniques, methods for security integration in agile. Existing techniques and methods have been scrutinized that have not impressively produced any significance review or survey based on this particular topic. For supposed investigations, Systematic literature review SLR technique has been used. Keeping in view of these investigations, a thorough exploration has been executed. The organization of the paper is: Sec. 2 includes the literature review, Sec. 3 includes the materials and methods, Sec. 4 includes the results and inferences, Sec. 5 includes the discussion and Sec. 6 includes conclusions.

\section{RELATED WORK}

The aim of this section is to elaborate the literature done on incorporating security in agile. Various methods are considered with different approaches to conduct surveys on incorporating security in agile.

Review on extreme programming was conducted by Ghani and Yasin [1]. They study literature related to the extreme programming with the perspective of security and they had observed that extreme programming partly supports integrating of security in it. Few of researchers worked on these topics, still comprehensive information regarding their outcome and usage was not published yet. They had concluded that the existing extreme programming practices are not adequate in term of security, hence new XP practices based upon security require to be proposed. Sani [9] conducted a literature survey on DSDM in term of security incorporated in it. From literature they had spotted that currently DSDM lack behind in providing support for secure development of software's. They find that only a single paper discuss about security integration in DSDM and no work done yet by the researchers for secure software development via DSDM. And their intention is to enhance current DSDM model so that it can support secure development. Ghani [10] performed a survey on it model that had been proposed by them for secure software development using DSDM in order to validate their model. After collecting, analyzing, comparing the results they had concluded that their model is very much beneficial in developing secure software using their enhanced DSDM model.

Adila[11] presented an extensive survey on feature driven development aim of literature survey is to study feature driven development with the intensions to produce a secure software. They find that there is no reputable research in respect of feature driven development and its integration with security and finally they had summarized that there is a need of revised feature driven model that can facilitate the secure development of software without compromising agile manifesto.

Oustlati [12] conducted a systematic review of agile development methodology and elaborates the challenges its face while developing secure software. They found 20 challenges in 10 studies and categorize them and founded that 14 out 20 challenges are valid in respect of agile methodology and 6 are invalid in case of agile principles. They concluded that secure software development using agile quite challenges, there is a lot of space for researchers to work in this area. 
Othmane [13] performed systematic review, and this review is just a mere extension of [12] above mentioned review. Parameters and results of both reviews are almost same but the difference exists between [12] and [13] is of the number of papers selected for both reviews, in [13] number of papers are double as comparable to paper selected by [12].

From above literature, it is extracted that the majority of studies focus on a particular agile practice such as XP, DSDM, FDD in their reviews[1,10,9,11]. And their focus is to identify that how much work is regarding security integration in agile or in particular agile practices and secondly scope of some studies $[12,13]$ are limited to fewer number of research papers. Although reviews performed in $[41,44]$ are very systematic but not much systematic in term of agile practices. The Intention of this study is to perform a comprehensive literature which is not limited to any specific agile practice and this study will take into account of all agile practices rather than to some specific practice of agile. Considering all agile practices in regards of secure software development in a systematic manner make our study unique from above mentioned studies.

\section{METHODOLOGY}

In this literature study, research methodology followed is Systematic Literature Review. A SLR is a mechanism of identifying, understanding and estimating complete existing research interrelated to a specific research query, topic area or matter of consideration. SLR involves following steps such as planning stage, conducting stage and reporting stage [14] complete procedure shown in (Fig.1). A unique research study facilitating a systematic review and known as primary research studies whereas a systematic review is a kind of secondary study.

The necessity for the systematic study (Step 1), the communal causes are:

- To precise the relevant research work evidences significant in term of incorporating security in agile.

- In order to mined out gaps in current research and to enhanced proposed parts for further investigation.

- Systematic reviews may be exercised to study the degree to which experimental evidence promotes/negate suppositions, or even to promote the development of novel theories. A search experiment was conducted recording the subsequent searched strings in ACM digital library, Springer and IEEE Xplore. The literature obtained from the string searching may possibly be helpful in discovering a trend for the software development and verification \&validation of the preferred search items and the desirable protocols.

(("Incorporating Security" OR "Integrated Software Security" OR "Secure Software Development" OR "Software Security") AND ("Agile Practices" OR "Dynamic Systems Development Method" OR "Extreme Programming" OR "Feature Driven Development") AND ("Challenges" OR "Issues")). 
- The research questions (Step 2) in section (3.1) indicate what should be extracted from the selected studies.

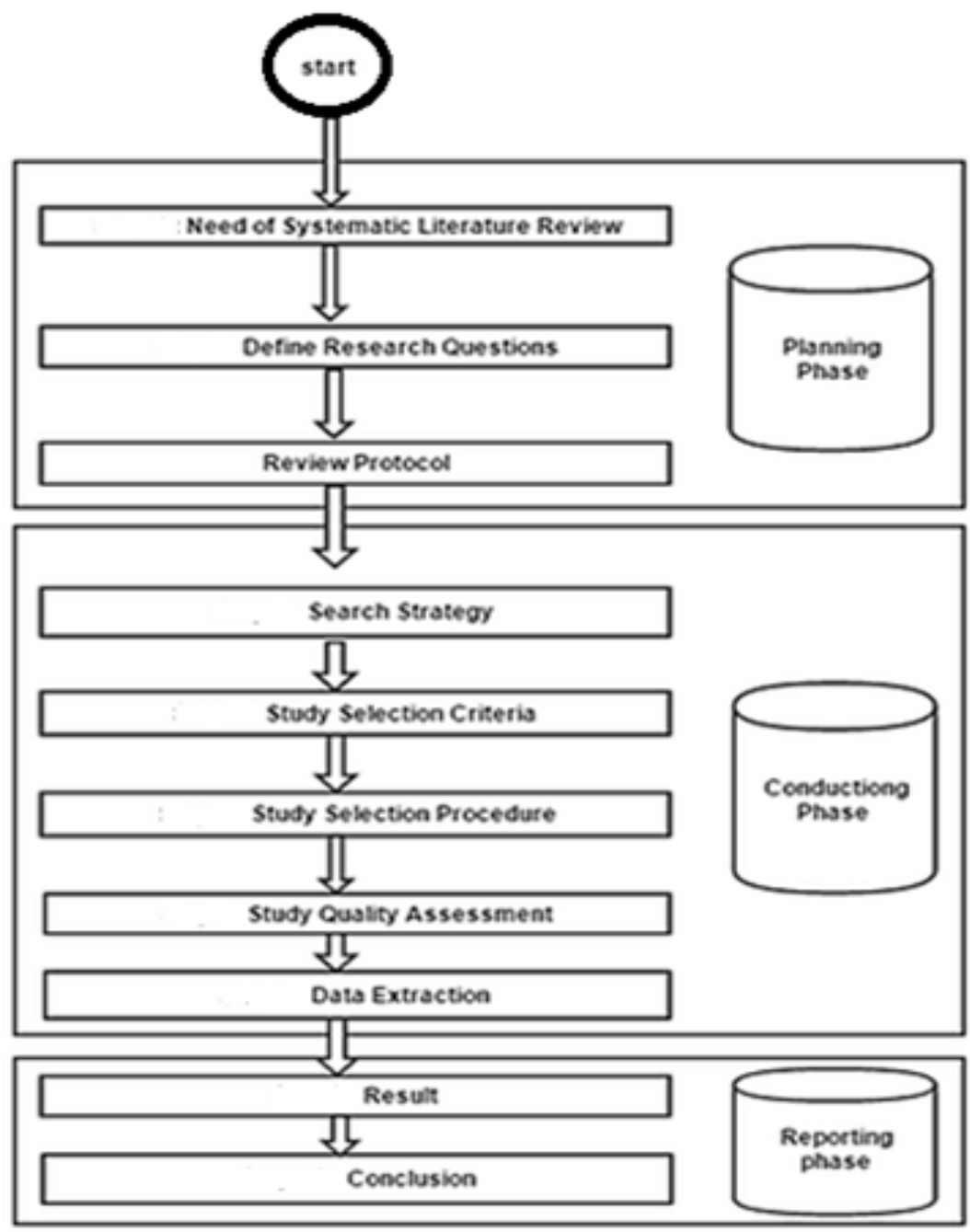

Figure 1: SLR Process

\section{1 . Research Questions}

(Staples, M. and Niazi, M.2007) [15]: encouraged the searching criteria that are being considered in order to assure the research papers quality and to exclude non-relevant work. The R. questions discussed in the work are as under:

RQ1. What types of approaches are being suggested for the purpose of security incorporation in agile and its practices? 
RQ2. What is the role of Security expert/ Engineer in these approaches?

RQ3. What kind of challenges emerges while incorporating security in agile and its practices?

The purpose of (Step 3) the protocol review ensures to overcome likely investigator's bias that will allow duplication in the study (Kitchen ham, 2007) [14]. In (Step 4,) the evaluation of protocol and the aid of drill in executing studies systematically by scholars. Depends on opinion and collected knowledge during the development, we repeatedly advanced the evaluation structure. The brief of the conclusive protocol is presented in sec. 3.2 to sec. 3.5.

\subsection{Search Strategy}

We adapted the procedure proposed in (as shown in Fig.2) for the selection of work. From the questions for research, we extracted the key-phrases for the mining. In order to validate the strings quality used for searching, we conducted a sample search on, IEEE Xplore, Science Direct and Google Scholar.

Figure 2: Search Strategy

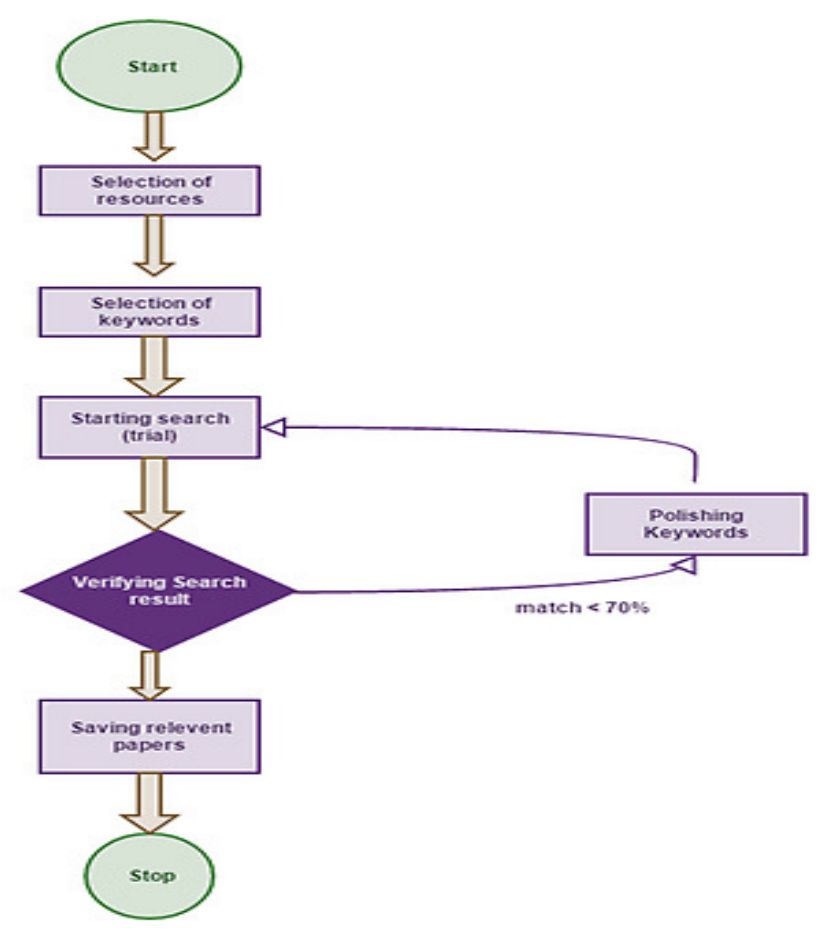




\subsection{Study Selection Criteria}

The vital aspects for concluding as primary study is data elaboration, depictingthat the studies to be used that are related to our key-phrases that are similar to those described in the test searchingis calculated shown in (Table.1) and therefore answering the research questions. So, all papers on incorporating security in agile and its practices will be incorporated.We eliminated non-English data that is books, text and presentations. We ignored material that was not included in our searched strings and non-relevant data to security in agile development and studies that do not satisfy agile development practices.

Table 1: Criteria for Selection Study

\begin{tabular}{|c|c|}
\hline Selection Of study & papers left \\
\hline Based on complete text & 45 \\
\hline Based on Abstract & 69 \\
\hline Based on title & 102 \\
\hline Based on searched strings & 172 \\
\hline
\end{tabular}

\subsection{Study Selection Procedure}

The study selection procedure (Step 5) was performed for the collection of a related analysis of the selection criteria between the investigators that organized the review. The selection criteria were implemented to the title and the abstract and essentially, for the complete text of the papers of the related area. As an experiment, we solely evaluated 69 randomly selected studies from a search conducted in ACM, Google Scholar, Springer and IEEE Xplore.

We documented the unclear explanation of the questions and selection principles on which the judgment for selection was exclusively grounded upon. We found total 45 papers, applying searching string, that have data interrelated to incorporating security in agile and its practices (as show $\mathrm{n}$ in Graph 1). We rejected documents that have emphasis on other domains than our related area of study. We aggregated needed sections from the papers to enhance the inferences towards success in finding incorporating security in agile (as shown in Fig.3). In addition, once more we read from selected papers and guaranteed that the papers selected are absolutely lawful as indication for integrated security in agile practices, (as shown in Table.2) as the outcomes\# per basis and increased points of indications gathered (as shown in Graph.2). 


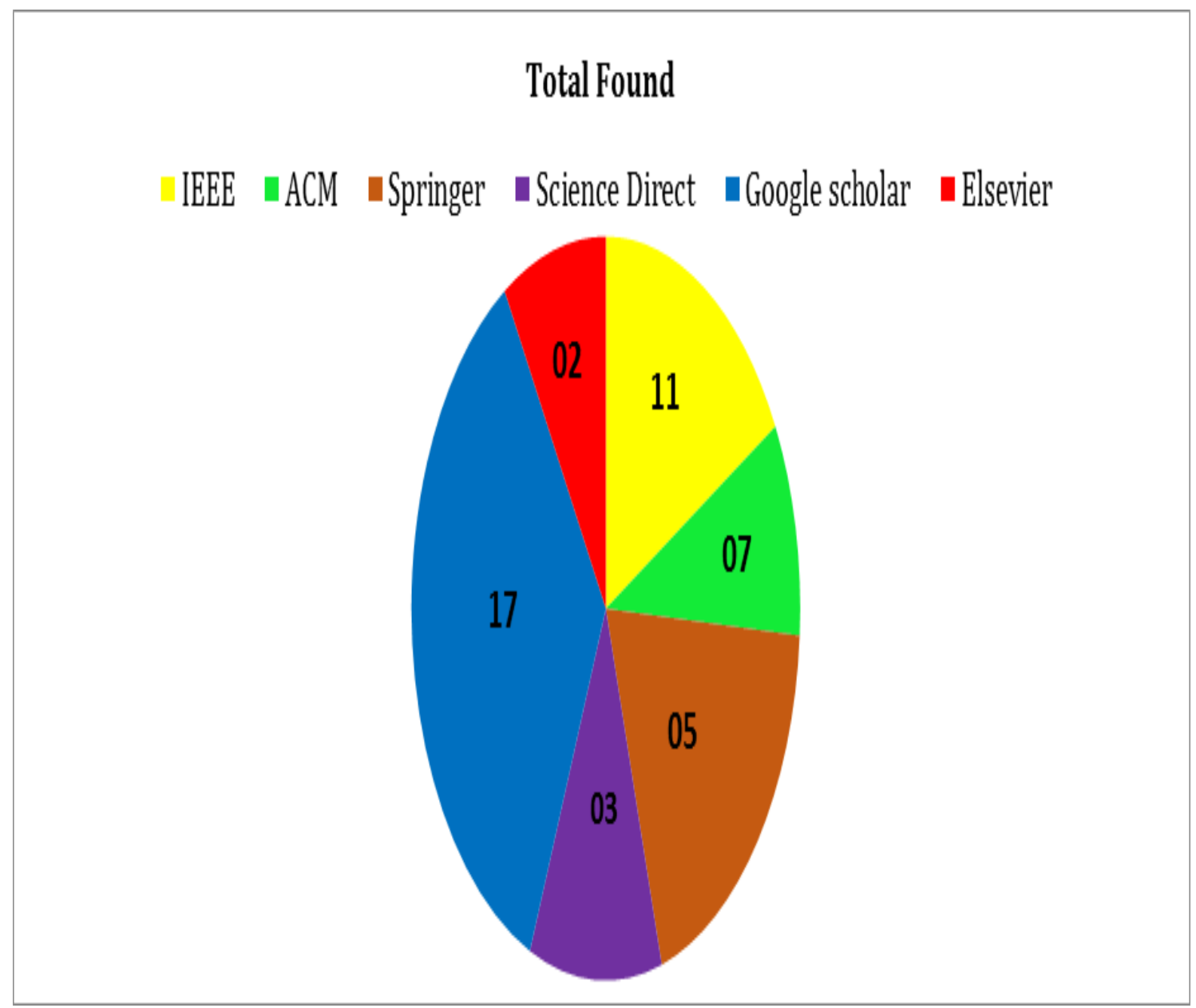

Graph 1: Selected Papers

\subsection{Study Quality Assessment}

In this section (Step 6) depicts the quality of our research. We hardly found relevant work for the questions that are entirely in support of our research work. Using data collected, we supported our choices and explorations. From QA-1, it is found that relevant approaches which incorporated security in agile and its practices. With QA2, we examined the challengesemerges while incorporating security in agile. With QA3, we evaluated those approaches were sufficient for integrated security in agile development. 
International Journal of Software Engineering \& Applications (IJSEA), Vol.7, No.3, May 2016

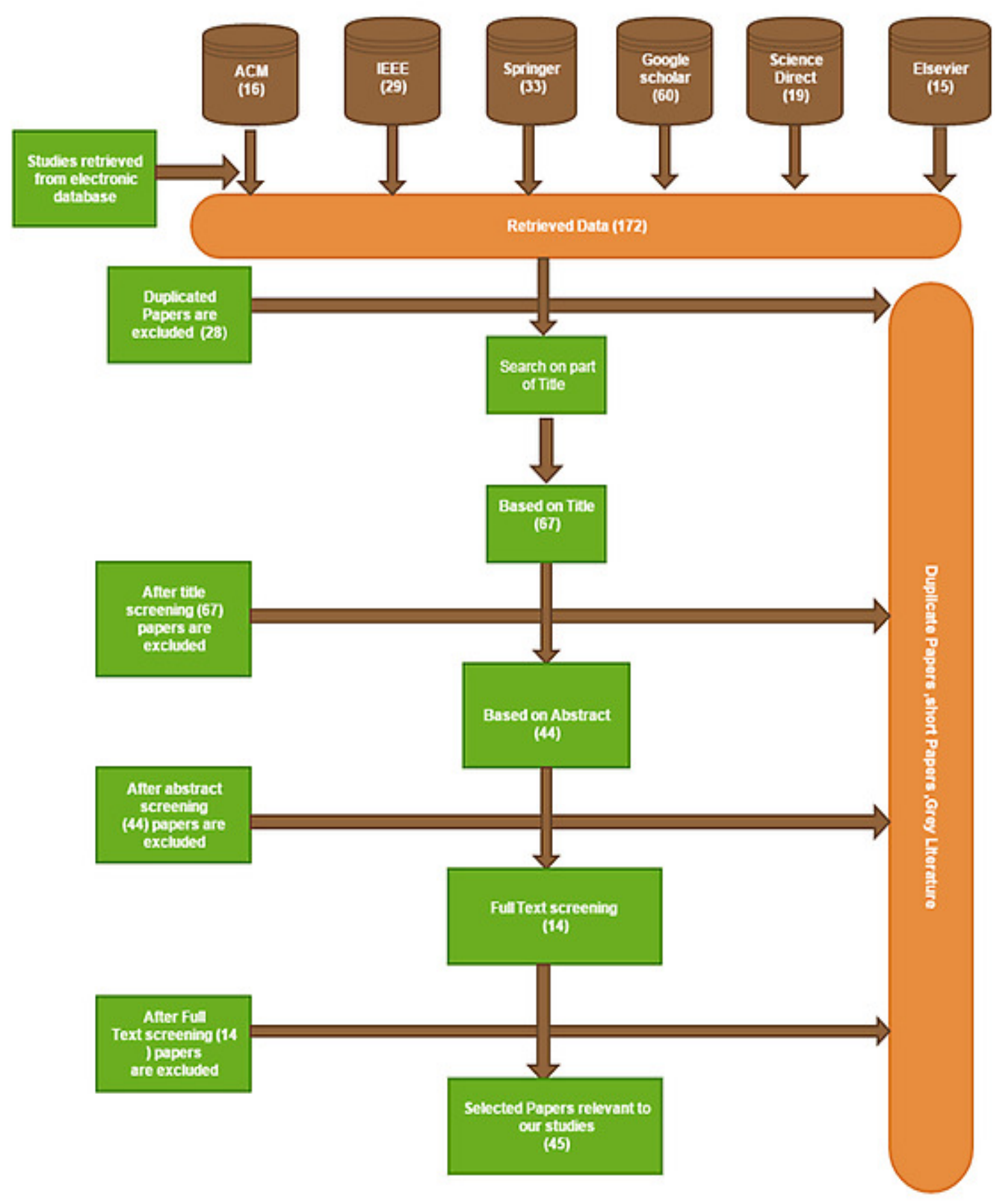

Figure 3: Selection of Primary Studies 
Table 2: Results over sources

\begin{tabular}{|l|c|c|c|c|c|c|}
\hline & IEEE & Google scholar & Elsevier & ACM & Science Direct & Springer \\
\hline Primary studies & 11 & 17 & 2 & 7 & 3 & 5 \\
\hline Total Found & 29 & 60 & 15 & 16 & 19 & 33 \\
\hline $\begin{array}{l}\text { Candidate } \\
\text { studies }\end{array}$ & 16 & 40 & 10 & 9 & 12 & 15 \\
\hline
\end{tabular}

\subsection{Data Extraction}

In the similar fashion, we break-down the work. Data extraction (Step 7) was achieved in a repetitive manner.We have endorsed the inferences given by [14]; it is predicted which might found challenging constituting a precedence a comprehensive group of charges for the whole belongings. We initiated the mining form with the attributes like research techniques, perspectives that displays the mapping to the particular. Questions addressed by the attribute (as shown in Table.3).

Table 3: Data Extraction

\begin{tabular}{|c|c|}
\hline Attributes & Research question \\
\hline Title/Year/Author & Overview of candidate literature \\
\hline Context & Overview of candidate literature \\
\hline Search Strategy & \\
\hline
\end{tabular}




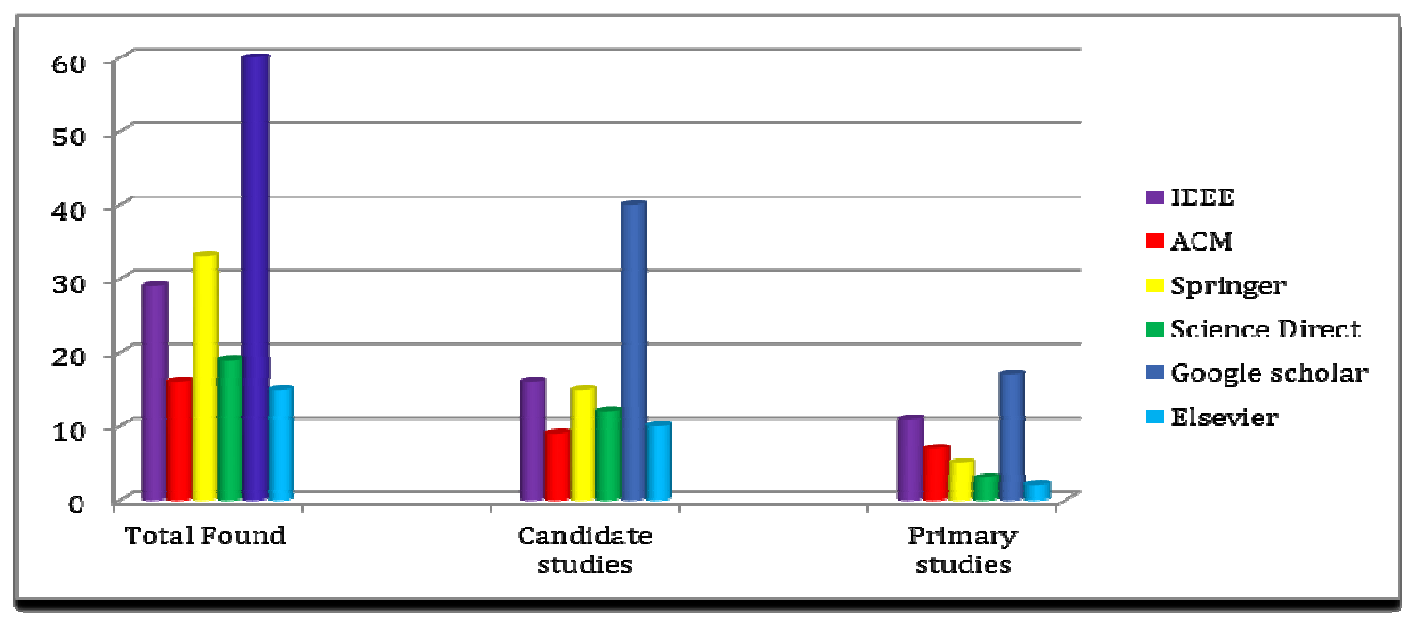

Graph 2: Number of results per sources

\section{RESULT AND ANALYSIS}

\section{RQ1. What types of approaches are being suggested for the purpose of security incorporation in agile and its practices?}

In order to answer to RQ1 we conduct a detailed analysis to facilitate our finding (see table 4).Twenty six studies are considered for analysis, foundation of considering studies in this particular review study is that only those studies are considered which provide any technique, method, principal framework for integrating security in agile methodology and its practices. The Parameters of this study were hauled out from numerous existing methodologies and studies were evaluated on the basis of succeeding parameters. (1) For which particular agile practice mechanism for security incorporation is provided [10]. (2) Involvement of security engineer/expert in particular technique [16], [17]. (3) Provision of framework or principal for security integration [10], [9]. (4) Research methodology used in the study [18]. (5) Domain consider in a particular paper. [19], [20].It has been observed that out total50\% of the studies consider integration of security in agile generally, while 15\% in Scrum, 23\% in XP, only 12\% in FDD and no study mention any mechanism for security integration in DSDM(see graph 3 ). These agile practices are included in this literature study because they are considered as popular among researchers and practitioners.

Table 4: Selected Studies Analysis

\begin{tabular}{|l|l|l|l|l|l|l|}
\hline Title & $\begin{array}{l}\text { Year Of } \\
\text { Publicatio } \\
\text { n }\end{array}$ & $\begin{array}{l}\text { Agile } \\
\text { Practice } \\
{[10]}\end{array}$ & $\begin{array}{l}\text { Involvement } \\
\text { of security } \\
\text { engineer/exp } \\
\text { ert } \\
{[16],[17]}\end{array}$ & $\begin{array}{l}\text { Framewo } \\
\text { rk/securi } \\
\text { ty } \\
\text { principal } \\
{[10],[9]}\end{array}$ & $\begin{array}{l}\text { Methodolog } \\
\text { [18] }\end{array}$ & $\begin{array}{l}\text { Domain } \\
{[19],[20]}\end{array}$ \\
\hline $\begin{array}{l}\text { Agile } \\
\begin{array}{l}\text { Development of } \\
\text { Secure Web } \\
\text { Applications [19] }\end{array}\end{array}$ & 2006 & FDD & No & Principal & Case Study & $\begin{array}{l}\text { Web } \\
\text { applicatio } \\
\text { ns }\end{array}$ \\
\hline
\end{tabular}


International Journal of Software Engineering \& Applications (IJSEA), Vol.7, No.3, May 2016

\begin{tabular}{|c|c|c|c|c|c|c|}
\hline $\begin{array}{l}\text { Agile Security } \\
\text { using an } \\
\text { incremental } \\
\text { architecture [21] }\end{array}$ & 2005 & Agile & No & Principal & Exploratory & $\begin{array}{l}\text { Not } \\
\text { mentioned }\end{array}$ \\
\hline $\begin{array}{l}\text { Agile } \\
\text { Development with } \\
\text { Security } \\
\text { Engineering } \\
\text { Activities [22] }\end{array}$ & 2011 & Agile & No & $\begin{array}{l}\text { Framewor } \\
\mathrm{k}\end{array}$ & Case Study & $\begin{array}{l}\text { Mobile } \\
\text { applicatio } \\
\mathrm{n}\end{array}$ \\
\hline $\begin{array}{l}\text { Improved } \\
\text { Extreme } \\
\text { Programming } \\
\text { Methodology with } \\
\text { Inbuilt Security } \\
\text { [23] }\end{array}$ & 2011 & $\mathrm{XP}$ & No & $\begin{array}{l}\text { Framewor } \\
\mathrm{k}\end{array}$ & Case Study & $\begin{array}{l}\text { Web } \\
\text { applicatio } \\
\text { ns }\end{array}$ \\
\hline $\begin{array}{l}\text { FISA-XP: An Agile- } \\
\text { based Integration } \\
\text { of Security } \\
\text { Activities with } \\
\text { Extreme } \\
\text { Programming [16] }\end{array}$ & 2014 & $\mathrm{XP}$ & Yes & $\begin{array}{l}\text { Framewor } \\
\mathrm{k}\end{array}$ & Experiment & $\begin{array}{l}\text { Not } \\
\text { mentioned }\end{array}$ \\
\hline $\begin{array}{l}\text { Selection of } \\
\text { Security Activities } \\
\text { for Integration } \\
\text { with Agile } \\
\text { Methods after } \\
\text { Combining their } \\
\text { Agility and } \\
\text { Effectiveness [24] }\end{array}$ & 2014 & Agile & Yes & $\begin{array}{l}\text { Framewor } \\
\mathrm{k}\end{array}$ & Exploratory & $\begin{array}{l}\text { Not } \\
\text { mentioned }\end{array}$ \\
\hline $\begin{array}{l}\text { A Novel Security- } \\
\text { Enhanced Agile } \\
\text { Software } \\
\text { Development } \\
\text { Process Applied in } \\
\text { an Industrial } \\
\text { Setting [25] }\end{array}$ & 2015 & Agile & Yes & $\begin{array}{l}\text { Framewor } \\
\mathrm{k}\end{array}$ & Experiment & $\begin{array}{l}\text { Mobile } \\
\text { applicatio } \\
\mathrm{n}\end{array}$ \\
\hline $\begin{array}{l}\text { Extending the } \\
\text { Agile } \\
\text { Development } \\
\text { Approach to } \\
\text { Develop } \\
\text { Acceptably Secure } \\
\text { Software [26] }\end{array}$ & 2014 & Agile & No & Principal & Case Study & $\begin{array}{l}\text { Web } \\
\text { applicatio } \\
\text { ns }\end{array}$ \\
\hline $\begin{array}{l}\text { ROLE-BASED } \\
\text { EXTREME } \\
\text { PROGRAMMING } \\
\text { (XP) FOR SECURE } \\
\text { SOFTWARE } \\
\text { DEVELOPMENT } \\
\text { [27] }\end{array}$ & 2013 & $\mathrm{XP}$ & Yes & $\begin{array}{l}\text { Framewor } \\
\mathrm{k}\end{array}$ & Exploratory & $\begin{array}{l}\text { Not } \\
\text { mentioned }\end{array}$ \\
\hline $\begin{array}{l}\text { Developing a } \\
\text { Secure website } \\
\text { using Feature }\end{array}$ & 2013 & FDD & No & $\begin{array}{l}\text { Not } \\
\text { mentioned }\end{array}$ & Case Study & $\begin{array}{l}\text { Web } \\
\text { applicatio } \\
\text { ns }\end{array}$ \\
\hline
\end{tabular}




\begin{tabular}{|c|c|c|c|c|c|c|}
\hline $\begin{array}{l}\text { Driven } \\
\text { Development } \\
\text { (FDD) [20] }\end{array}$ & & & & & & \\
\hline $\begin{array}{l}\text { Risk-Driven } \\
\text { Security Metrics } \\
\text { in Agile Software } \\
\text { Development - An } \\
\text { Industrial Pilot } \\
\text { Study [28] }\end{array}$ & 2012 & Agile & No & $\begin{array}{l}\text { Framewor } \\
\mathrm{k}\end{array}$ & Experiment & $\begin{array}{l}\text { Mobile } \\
\text { applicatio } \\
\mathrm{n}\end{array}$ \\
\hline $\begin{array}{l}\text { Secure Software } \\
\text { Development } \\
\text { Model: A Guide for } \\
\text { Secure Software } \\
\text { Life Cycle [29] }\end{array}$ & 2010 & $\mathrm{Xp}$ & Yes & $\begin{array}{l}\text { Framewor } \\
\mathrm{k}\end{array}$ & Exploratory & $\begin{array}{l}\text { Not } \\
\text { mentioned }\end{array}$ \\
\hline $\begin{array}{l}\text { S-Scrum: a Secure } \\
\text { Methodology for } \\
\text { Agile } \\
\text { Development of } \\
\text { Web Services [30] }\end{array}$ & 2013 & Scrum & No & $\begin{array}{l}\text { Framewor } \\
\mathrm{k}\end{array}$ & Case Study & $\begin{array}{l}\text { Web } \\
\text { applicatio } \\
\text { ns }\end{array}$ \\
\hline $\begin{array}{l}\text { Towards Agile } \\
\text { Security } \\
\text { Assurance [31] }\end{array}$ & 2005 & Agile & No & Principal & Exploratory & $\begin{array}{l}\text { Not } \\
\text { mentioned }\end{array}$ \\
\hline $\begin{array}{l}\text { Extending XP } \\
\text { Practices to } \\
\text { Support } \\
\text { Security } \\
\text { Requirements } \\
\text { Engineering [32] }\end{array}$ & 2006 & $\mathrm{XP}$ & Yes & $\begin{array}{l}\text { Framewor } \\
\mathrm{k}\end{array}$ & Experiment & $\begin{array}{l}\text { Web } \\
\text { applicatio } \\
\text { ns }\end{array}$ \\
\hline $\begin{array}{l}\text { Security Planning } \\
\text { and Refactoring in } \\
\text { Extreme } \\
\text { Programming [33] }\end{array}$ & 2006 & $\mathrm{XP}$ & No & Principal & Case Study & $\begin{array}{l}\text { Web } \\
\text { applicatio } \\
\text { ns }\end{array}$ \\
\hline $\begin{array}{l}\text { Security Backlog } \\
\text { in Scrum Security } \\
\text { Practices [34] }\end{array}$ & 2011 & Scrum & Yes & $\begin{array}{l}\text { Framewor } \\
\mathrm{k}\end{array}$ & Exploratory & $\begin{array}{l}\text { Not } \\
\text { mentioned }\end{array}$ \\
\hline $\begin{array}{l}\text { Integrating } \\
\text { Security into Agile } \\
\text { Development } \\
\text { Methods [35] }\end{array}$ & 2005 & Agile & No & Principal & Case Study & $\begin{array}{l}\text { Web } \\
\text { applicatio } \\
\text { ns }\end{array}$ \\
\hline $\begin{array}{l}\text { Development of } \\
\text { Agile Security } \\
\text { Framework Using } \\
\text { a Hybrid } \\
\text { Technique for } \\
\text { Requirements } \\
\text { Elicitation [17] }\end{array}$ & 2011 & Agile & Yes & $\begin{array}{l}\text { Framewor } \\
\mathrm{k}\end{array}$ & Case Study & $\begin{array}{l}\text { Not } \\
\text { mentioned }\end{array}$ \\
\hline $\begin{array}{l}\text { Integration } \\
\text { Analysis of } \\
\text { Security Activities } \\
\text { from the } \\
\text { perspective of } \\
\text { agility[36] }\end{array}$ & 2012 & Agile & Yes & Principal & Exploratory & $\begin{array}{l}\text { Not } \\
\text { mentioned }\end{array}$ \\
\hline Integrating & 2008 & Agile & Yes & Principal & Exploratory & Not \\
\hline
\end{tabular}




\begin{tabular}{|c|c|c|c|c|c|c|}
\hline $\begin{array}{l}\text { Software } \\
\text { Development } \\
\text { Security Activities } \\
\text { with Agile } \\
\text { Methodologies[37 } \\
\text { ] }\end{array}$ & & & & & & mentioned \\
\hline $\begin{array}{l}\text { Using Assurance } \\
\text { Cases to Develop } \\
\text { Iteratively } \\
\text { Security Features } \\
\text { Using Scrum[38] }\end{array}$ & 2014 & Scrum & No & $\begin{array}{l}\text { Framewor } \\
\mathrm{k}\end{array}$ & Case study & $\begin{array}{l}\text { Communic } \\
\text { ation }\end{array}$ \\
\hline $\begin{array}{l}\text { Secure Feature } \\
\text { Driven } \\
\text { Development } \\
\text { (SFDD) Model for } \\
\text { Secure Software } \\
\text { Development[39] }\end{array}$ & 2013 & FDD & Yes & $\begin{array}{l}\text { Framewor } \\
\mathrm{k}\end{array}$ & Exploratory & $\begin{array}{l}\text { Not } \\
\text { mentioned }\end{array}$ \\
\hline $\begin{array}{l}\text { Secure Scrum: } \\
\text { Development of } \\
\text { Secure Software } \\
\text { with Scrum[40] }\end{array}$ & & Scrum & No & $\begin{array}{l}\text { Framewor } \\
\mathrm{k}\end{array}$ & Survey & $\begin{array}{l}\text { Not } \\
\text { mentioned }\end{array}$ \\
\hline $\begin{array}{l}\text { The Creation of a } \\
\text { Distributed Agile } \\
\text { Team [41] }\end{array}$ & 2007 & Agile & No & $\begin{array}{l}\text { Framewor } \\
\mathrm{k}\end{array}$ & Exploratory & $\begin{array}{l}\text { Web } \\
\text { Services }\end{array}$ \\
\hline $\begin{array}{l}\text { Towards Agile } \\
\text { Security in Web } \\
\text { Applications [42] }\end{array}$ & 2006 & Agile & YES & Principal & Exploratory & $\begin{array}{l}\text { Not } \\
\text { mentioned }\end{array}$ \\
\hline
\end{tabular}

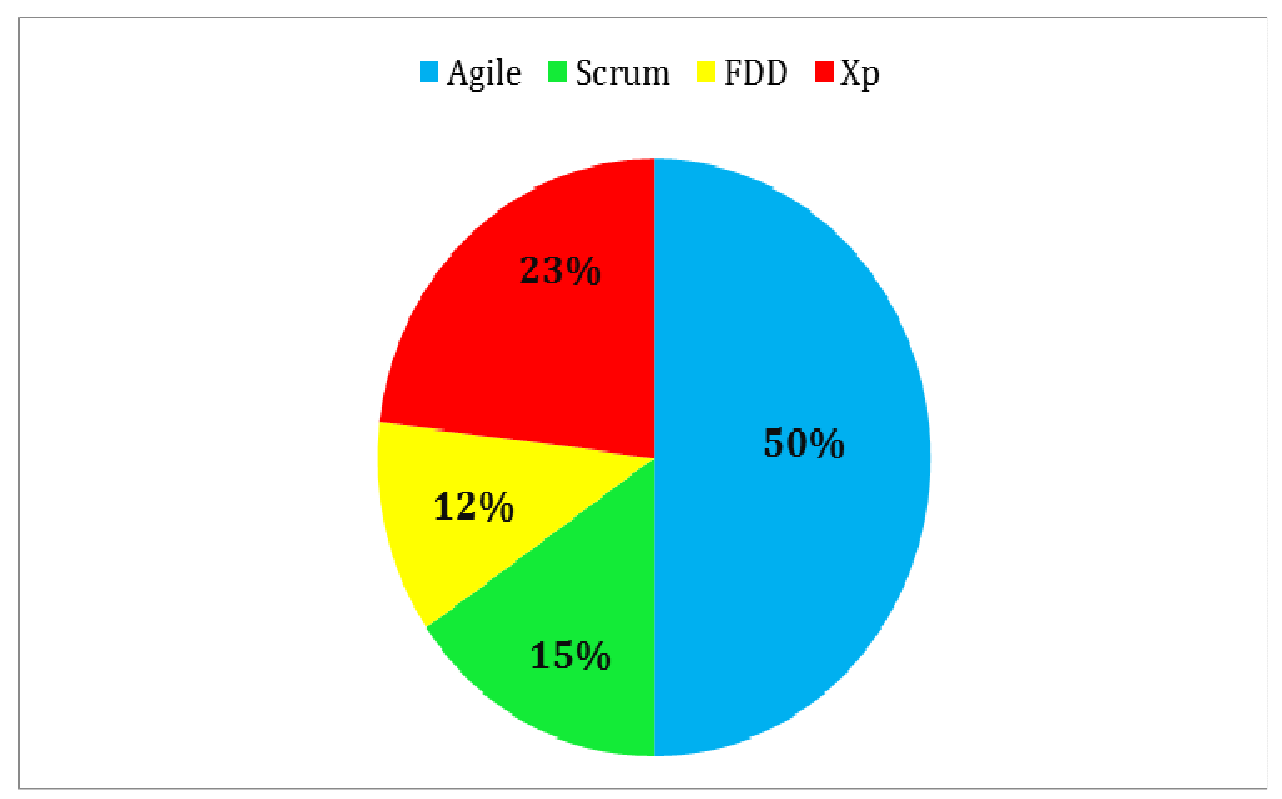

Graph 3: Agile practices that integrate security 


\section{RQ2. What is the role of Security expert/Engineer in these approaches?}

In order to develop secure software, it is important to have a dedicated person that has a fair amount of knowledge about software security or in other word require security expert[24], [16]. Security experts should be responsible for proper integration of security in particular software system [24], [36]. Traditionally involvement of security expert in agile software development for developing secure software is considered as overhead [27]. But it has been observed that for developing secure software using agile it is important to have a security expert and it will increase the level of agility in development [16], [36]. Most of the time development teams are not aware and familiar of security related construct and issues in the developing secure software and because of lack of expertise in term of security it is difficult for developers to properly integrate security in projects and increase the development time which in turn effect deliverable time of agile increments [36],[29]. Thus, it is important to have the involvement security expert in agile methodology to facilitate secure development. From literature that has been sighted it is extracted that $54 \%$ studies had not mentioned the involvement of security expert in their approaches that has been proposed for secure software development using Agile and its practices which is a major drawback of these techniques and rest of $46 \%$ mentioned the involvement of security expert in their approaches (see graph 4)

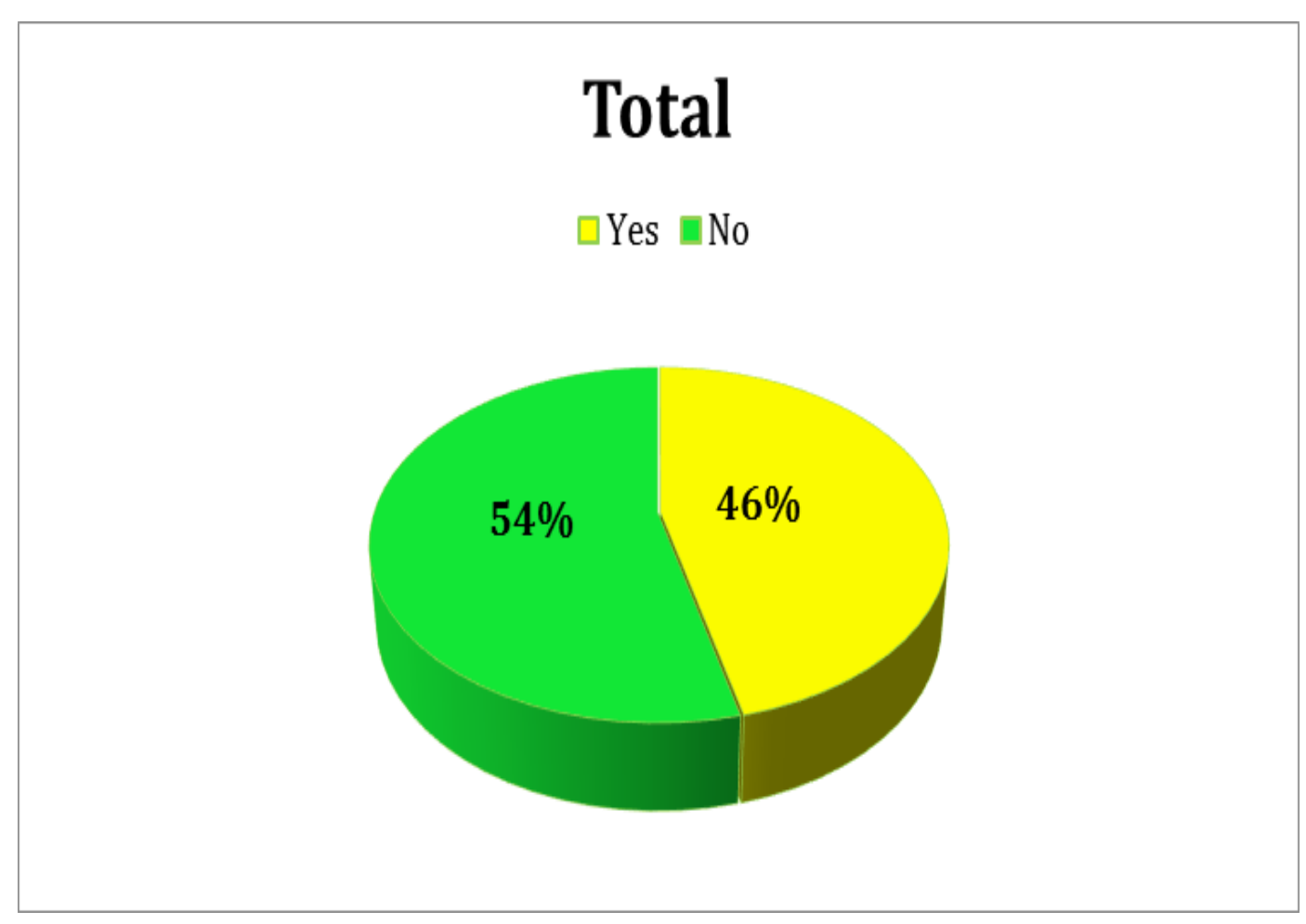

Graph 4: Numbers of studies involving security expert

$46 \%$ of studies encourage the participation of security engineer, after analyzing the studies encouraging the participation of security expert it is spotted that [36], [16], [24], [37] calculate the 
agility degree of various security activities using different techniques and proposed that the activity with high agility degree needs to be integrated with agile methods so that it will not disturb the agility of methods. If security engineer is involved throughout the development process it is being assigned high value of agility and partial involvement is assigned as low values of agility [16]. Rest of studies practically involved security expert in their proposed techniques. We have analyzed these studies on the basis of two parameters which are derived from the above discussion. (P1) involvement of security expert throughout the development lifecycle or in any particular phase while (P2) clear definition and description of roles and responsibilities of security expert.(See Table 5)

Table 5: Involvement of Security Expert in SDLC phases

\begin{tabular}{|c|l|c|}
\hline Paper & \multicolumn{1}{|c|}{ P1 } & P2 \\
\hline$[\mathbf{2 5}]$ & Throughout development lifecycle & $\checkmark$ \\
\hline$[\mathbf{2 7}]$ & Not mentioned & $\mathbf{x}$ \\
\hline$[\mathbf{2 9}]$ & Requirement engineering\& design phase & $\mathbf{x}$ \\
\hline$[\mathbf{3 2}]$ & Requirement engineering phase & $\checkmark$ \\
\hline$[\mathbf{3 4}]$ & Documentation, analysis \& testing phase & $\mathbf{x}$ \\
\hline$[\mathbf{1 7}]$ & Requirement engineering phase & $\mathbf{x}$ \\
\hline$[\mathbf{3 9}]$ & Documentation, Development \& testing phase & \\
\hline
\end{tabular}

In (table 5) only [25] encourage the throughout involvement of security expert's during the development life cycle with defined roles, but major drawback of this approach is that it involves security expertise more than required like security manager, security architect, security expert. Involving a number of security experts e.g. 3 or more security related personals in agile team don't seem to be effective and may consider as overhead, whereas [34] doesn't involve expert throughout development life cycle and partially define the role and responsibilities of security expert.

\section{RQ3. What kind of challenges emerges while incorporating security in agile and its practices?}

Underneath are some of the challenges that are reported in the literature that limit agile methodology and its practices to produce secure software (see Table 6). It is observed that challenge $\mathrm{Ch} 1, \mathrm{Ch} 5, \mathrm{Ch} 10$, and $\mathrm{Ch} 12$ are closely related to the collaboration and awareness among stakeholder in an agile development environment. Challenge Ch2, Ch4, Ch7, Ch11 are often caused due to the iterative and incremental nature of agile development methodology. Challenge Ch3, Ch9 have occurred as a consequence of security assurance of agile increments. $\mathrm{Ch} 6, \mathrm{Ch} 8, \mathrm{Ch} 13$ are directly related to the development life cycle of agile. In Oder to improve 
agile methodology and its practices to provide secure software, it is quite necessary to eliminate these challenges or to trigger down their effect to possible minimal level.

Table 6: Agile security challenges

\begin{tabular}{|l|l|l|}
\hline Code & Challenge & Papers \\
\hline Ch1 & Need of separation of roles between software developer and security expert & {$[42],[40],[37],[29]$} \\
\hline Ch2 & $\begin{array}{l}\text { Security assurance of increment \& activities are difficult if the code is changing } \\
\text { continuously. }\end{array}$ & {$[31],[26]$} \\
\hline Ch3 & Detailed documentation is required for security assessment & {$[31],[42]$,} \\
\hline Ch4 & Security constraints are violated due to refracting & {$[31],[33]$} \\
\hline Ch5 & Lack of experience of developers in developing secure software & {$[29],[20],[24]$} \\
\hline Ch6 & Neglecting risk assessment & {$[32],[28],[19]$} \\
\hline Ch7 & Security requirements are difficult to track if requirements change frequently. & {$[32]$} \\
\hline Ch8 & Security measure is not considered in every iteration & {$[31],[23],[19],[26]$} \\
\hline Ch9 & $\begin{array}{l}\text { Test cases are not adequate to ensure the integration of security related } \\
\text { requirement }\end{array}$ & {$[31],[24]$} \\
\hline Ch10 & Lack of security requirements and considerations & {$[7],[17]$} \\
\hline Ch11 & $\begin{array}{l}\text { Requirements change and design change violate the security requirement of } \\
\text { the system. }\end{array}$ & {$[32],[17]$} \\
\hline Ch12 & Unawareness of customer in term of security & {$[34],[39]$} \\
\hline Ch13 & Neglecting security requirements in elicitation phase & {$[32],[19],[17]$} \\
\hline
\end{tabular}

\section{DISCUSSION}

After reviewing and analyzing the literature, it is observed that involvement of security expert throughout the development life cycle is necessary in order to cater security related concern and for proper integration of security in agile increment. In the majority of studies (54\%) security expert is unavailable and seems that it is undefined, who will be responsible for maintaining security of agile increments and deliverables. In the absence of security expert it is hard to define that who will be responsible for this critical task, because it is quite unjustified to handover this critical task to individuals having limited knowledge and background of software security. If this important and critical task is assigned to teams or individuals who are not expert in the field of software security it will not only increase the cost in term of time and negatively affects the quality of software in term of security.

Out of the total $45 \%$ of the studies mentioned the involvement of security expert in their techniques, but the major draw of these studies is that they are not facilitating the involvement of security expert throughout development life cycle and secondly there is no clear description of roles and responsibilities of security expert. Ch1, Ch5 and Ch12 (see table) can be catered by involving security expert with defined and separate roles and responsibilities in software development life cycle, Ch13 and Ch10 can be managed by the involvement of security expert in requirements engineering phase by taking into account of security requirements. Involving security expert in the construction phase can affect $\mathrm{Ch} 7, \mathrm{Ch} 8$ and $\mathrm{Ch} 11$ positivity by having a critical eye on the construction phase in term of security. $\mathrm{Ch} 2, \mathrm{Ch} 9$ can be handled by involving security expert in testing and transition phase. 
From the consequence of the above discussion, it is mined that useful techniques has been proposed in regard of developing secure software using agile. The Major weakness of these techniques due which they are not able to properly integrate security in agile are lack of involvement of a security expert, or if involved, then he was not been involved throughout the development life cycle and his roles and responsibilities are not defined. So it is quite important to have the involvement of security expert with defining roles and responsibilities throughout the agile development life cycle, i.e. in inception, construction and transition phase, in order to take care of security related aspect of software and for fruitful integration of security in every agile

iteration and deliverable. It has hauled out from literature that if security is not considered in every phase of the agile development cycle, it makes secure software development challenging and leaves possible glitches in developed software in term of security.

\section{CONCLUSION}

To gain insight into the current status of security in Agile Development Cycle and its techniques, a systematic literature review (SLR) has been conducted that highlights the current issues of security in Agile practices. Agile has been criticized for lacking security due to its incremental approach. Some complications have been highlighted such as lack of consideration of security throughout the agile development life cycle and absence of the dedicated resource person, having a fair knowledge of software security, with defined responsibilities. From review it has been observed that some researcher has agreed that there should be a defined role to fulfil security aspects in complete lifecycle. In the future, we are planning to develop a framework in order to address the issues mentioned in this paper for security integration in agile properly and correctly with ease and to obtain better results.

\section{REFRENCES}

[1] I. Ghani, \& I.Yasin, (2013) "Software Security Engineering In Extreme Programming Methodology: A Systematic Literature", Science International Volume No.25 (2), pp-215-221.

[2] M. V. Mohamed, (2014) "Implementation of Scrum Framework of Agile Methodology for an Online Project", International Journal of Emerging Technology \& Advance Engineering, Volume 4 (7), pp435-440

[3] R. C. Martin, (2003.) “Agile Software Development: Principles, Patterns, and Practices”, 1st ed. Upper Saddle River, NJ, USA: Prentice Hall PTR,

[4] T. Dyba \& T. Dingsoyr, (2008) "Empirical studies of agile software development: A systematic review," Information and Software Technology Elsevier, vol. 50, (9) 10, pp. 833 - 859

[5] J. Wäyrynen, M. Bodén. \& G. Boström, Security (2004) "Engineering and extreme Programming: An Impossible Marriage?" In Proceedings of the 4th Conference on Extreme Programming and Agile Methods. 2004, Springer-Verlag, Lecture Notes in Computer Science, pp. 117

[6] J. C. Alberts, \& R. S. Allen, (2011) "Risk based measurement and analysis: Application to software security”, Software Engineering Institute, Carnegie Mellon University Pittsburgh.

[7] S. Bryan, Streamline (2010) "Security Practices for Agile Development". MSDN Magazine.

[8] C. Zannier, H. Erdogmus \& Lowell Lindstrom (2002), "On bricks and walls: Why building secure software is hard, "Computers\& Security", vol. 21(3), pp. 229-238. 
International Journal of Software Engineering \& Applications (IJSEA), Vol.7, No.3, May 2016

[9] A. Sani, \& A. Firdaus, (2013), "A Review on Software Development Security Engineering using Dynamic System Method ( DSDM )", International Journal Of Computer Applications, Volume No. 69 (25), pp-37-44.

[10] I. Ghani, N. Niknejad, M. Bello, M. W. Chughtai, \& S. R. Jeong, (2015) " ( SDSDM ): A Survey About Its Suitability", Journal of Theoretical and Applied Information Technology, Volume No.74 (1).

[11] A. Firdaus, A. Universiti, I. Ghani, \& Teknologi, (2014) "A Systematic Literature Review on Secure Software Development using Feature Driven Development ( FDD ) Agile Model", Journal of the Society for Internet Information, Article No 15 (1), pp. 13-27 http://doi.org/10.7472/jksii.2014.15.1.13.

[12] H. Oueslati, (2015) "Literature Review of the Challenges of Developing Secure Software Using the Agile Approach" $10^{\text {th }}$ IEEE International Conference on Availability, Reliabilty \& security, pp. 540547.

[13] Oueslati et al., (2016) "Evaluation of the challenges of developing secure software using agile approach". International Journal of secure software Enginerring Volume 7 ( 4).

[14] B. Kitchenham, R. Pretorius, D. Budgen, O. P. Brereton, M. Turner, M. Niazi, \& S. Linkman, (2010) "Systematic literature reviews in software engineering - A tertiary study". Information and Software Technology, Volume No.52 (8), pp- 792-805. http://doi.org/10.1016/j.infsof.2010.03.006

[15] M. Staples, \& M. Niazi, (2007). "Experiences Using Systematic Review Guidelines". Journal of Systems and Software, ACM, Vol. 80(9) pp. 1425-1437.

[16] S. Singhal, \& H. Banati, (2014) "Fisa-Xp". ACM SIGSOFT Software Engineering Notes, volume 39(3),. pp.1-14. http://doi.org/10.1145/2597716.2597728

[17] A. Singhal, (n.d.). (2011) "Development of Agile Security Framework Using a Hybrid Technique for Requirements Elicitation", Advances in communiaction \& control Springer Berlin Heidelberg.

[18] G. E. Richard, (April 2008), "Getting Students to Think about How Agile Processes Can Be Made More Secure", 21st IEEE Conference on Software Engineering Education and Training pp.51-58.

[19] X. Ge, R. F. Paige, F. a. C. Polack, H. Chivers, \& P. J. Brooke, (2006) "Agile development of secure web applications". Proceedings of the 6th International Conference on Web Engineering, ACM ICWE' 06, pp. 305-312 http://doi.org/10.1145/1145581.1145641

[20] A. Firdaus, I. Ghani, Izzaty, \& M. Yasin, ( 2013) "Developing Secure Websites Using Feature Driven Development (FDD ): A Case Study", Journal of clean Energy Technology, volume 01(4). http://doi.org/10.7763/JOCET.2013.V1.73

[21] H. Chivers, R. F. Paige, \& X. Ge, (2005) "Agile Security Using an Incremental Security Architecture", Extreme Programming and Agile Processes in Software Engineering. Springer Berlin Heidelberg, pp. 57-65.

[22] B. Carlsson, (2011) "Agile Development with Security Engineering Activities", Proceedings of the 2011 International Conference on Software and Systems Process. ACM, pp. 149-158.

[23] S, B. M., \& N. Norwawi, (2011) "Improved Extreme Programming Methodology with Inbuilt Security", IEEE Symposium on Computers \& Informatics pp. 674-679.

[24] A. Singhal, (n.d.). (2014) "Selection of Security Activities for Integration with Agile Methods after Combining their Agility and Effectiveness,"volume 6 (2), pp. 57-67

[25] D. Baca, M. Boldt, B. Carlsson, \& A. Jacobson, (2015) "A Novel Security-Enhanced Agile Software Development Process Applied in an Industrial Setting", 10th International Conference on Availability, Reliability and Security. http://doi.org/10.1109/ARES.2015.45.

[26] L. Othmane, P. Angin, H. Weffers, \& B. Bhargava, (2014) "Extending the Agile Development Approach to Develop Acceptably Secure Software", Dependable and Secure Computing, IEEE Transactions on volume 11(06), pp 1-14. http://doi.org/10.1109/TDSC.2014.2298011

[27] I. Ghani, \& A. Firdaus. (2013) "Role-Based Extreme Programming ( Xp ) For Secure sofware Development" Vol. 25, 
International Journal of Software Engineering \& Applications (IJSEA), Vol.7, No.3, May 2016

[28] R. M. Savola, C. Frühwirth, \& Pietikäinen, (2012) "A. Risk-Driven Security Metrics in Agile Software Development - An Industrial Pilot Study", Journal of Universal computer Science, volume 18( 12) , pp.1679-1702.

[29] M. I. Daud, (2010 ) "Secure Software Development Model: A Guide for Secure Software Life Cycle.", International Multiconference of Engineers and computer scientist volume No.1. pp. 17-19.

[30] D. Mougouei, N. Fazlida, M. Sani, \& M. M. Almasi, (2013) "S-Scrum : a Secure Methodology for Agile Development of Web Services", world of computer science \& Information Technology Journal volume No. 3 (1), pp. 15-19.

[31] K. Beznosov, \& P. Kruchten, (2005), "Towards Agile Security Assurance", Proceedings of the 2004 workshop on New security paradigms. ACM, pp. 47-54.

[32] Boström, K. Beznosov, \& P. Kruchten, (2006) "Extending XP Practices to Support Security Requirements Engineering", International workshop on software enginerring for secure system , ACM pp. 11-18.

[33] E. G., Aydal, R. F. Paige, H. Chivers, \& P. J. Brooke, (2006) "Security Planning and Refactoring in Extreme Programming", Springer Berlin Heidelberg, pp. 154-163.

[34] Z. Azham, (2011) "Security Backlog in Scrum Security Practices" $5^{\text {th }}$ Malaysian Conference on IEEE, pp. $414-417$

[35] M. Siponen, R. Baskerville \& T. Kuivalainen, 2005 "Integrating Security into Agile Development Methods", System Sciences, 2005. HICSS'05. Proceedings of the 38th Annual Hawaii International Conference on. IEEE, pp.185a-185a

[36] Singhal, A. (2012). "Integration Analysis of Security Activities from the perspective of agility" Conference on IEEE http://doi.org/10.1109/AgileIndia.2012.9

[37] H. Keramati, (2008) "Integrating Software Development Security Activities with Agile Methodologies", Computer System \& Application International conference on IEEE, pp 749-754.

[38] L. Othmane, (2014) "Using Assurance Cases to Develop Iteratively Security Features Using Scrum", ${ }^{\text {th }}$ International Conference on IEEE http://doi.org/10.1109/ARES.2014.73.

[39] A. Firdaus, I. Ghani, \& S. Ryul, (2014) "Secure Feature Driven Development ( SFDD ) Model for Secure Software Development" 2nd International Conference on Innovation, Management and Technology Research Procedia - Social and Behavioral Sciences Elsevier, Volume No.129, pp. 546553. http://doi.org/10.1016/j.sbspro.2014.03.712.

[40] C.Pohl, (n.dl.). ( 2015) "Secure Scrum : Development of Secure Software with Scrum" arXiv preprint arXiv: 1507.02992.

[41] P, K \& F Cannizzo, British, (2007) "The Creation of a Distributed Agile Team", In Agile Processes in Software Engineering and Extreme Programming, Springer Berlin Heidelberg pp. 235-239.

[42] V. Kongsli, (2006) "Towards Agile Security in Web Applications", Companion to the 21st ACM SIGPLAN symposium on Object-oriented programming systems, languages, and applications. ACM, pp. 805-808.

[43] Usman Rafi, Tasleem Mustafa, (2015) "US-Scrum: A Methodology for Developing Software with Enhanced Correctness, Usability and Security". International Journal of Scientific \& Engineering Research, Volume 6, (9), 377 ISSN 2229-5518. pp- 377-383.

[44] A. A. Liza, M. G. Andrew, B.W. Gary, (2012)" Emergence of Agile Methods: Perceptions from Software" Practitioners in Malaysia, Conference of IEEE Agile India, pp. 30-39

[45] A. Tuli, et al. (2014), "Empirical investigation of agile software development: cloud perspective." ACM SIGSOFT Software Engineering Volume 39(4) pp. 1-6 


\section{Authors}

Raja Khaim Shahzad was born in Islamabad, Pakistan. He is research student, done BS (CS) from PMAS Arid Agriculture University Rawalpindi, Pakistan in 2012, now doing MS (CS) from same University. His research area is software engineering, agile software development, software Security, Information Security

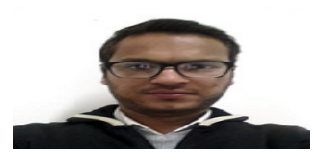

Saba Naz, research student, done MCS from International Islamic University Islamabad, Pakistan in 2013, now doing MS (CS) from PMAS Arid Agriculture University Rawalpindi, Pakistan. Her research area is image processing, software security, information security, data mining.

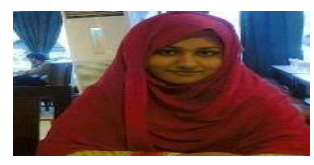

Syed Fakhar Abbas, research student, done MCS from PMAS Arid Agriculture University Rawalpindi, Pakistan in 2009, now doing now doing MS (CS) from same University. His research area is software engineering and web development.

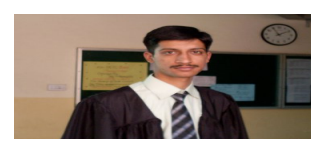

Naila Iqbal research student, done BSCS from Fatimah Jinnah University Rawalpindi, Pakistan in 2013, now doing MS (CS) from PMAS Arid Agriculture University Rawalpindi, Pakistan. Her research area is software engineering, agile software development and requirement Engineering.

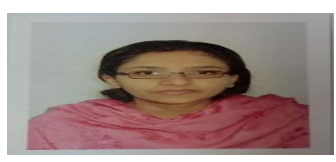

Mamoona Humayun is Ph.D. in computer science by Harbin Institute of Technology, Harbin China, in 2014. She is assistant professor at University Institute of Information Technology, PMAS-Arid Agriculture University Rawalpindi. Her research interests are Global software development, requirement engineering, and knowledge management and web application security vulnerabilities.

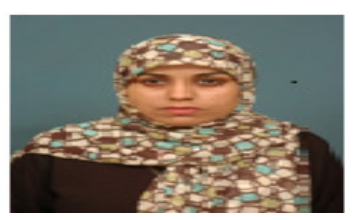

